\title{
TUNE-BOOK IMPRINTS IN CANADA TO 1867: A DESCRIPTIVE BIBLIOGRAPHY
}

Tune-books, collections of music for use in conjunction with words-only psalm and hymn books, have played a most important role in the development of North American musical life. Their publication history is rooted in New England and the efforts launched there in the early 1720 s to combat a serious decline, since the days of early settlement, of church-goers' ability to sing the metrical psalm tunes properly. At the urging of the eloquent Thomas Symmes and other Boston clergymen, groups of people began to meet with instructors several evenings a week to learn "Regular Singing", or the art of singing by note. Within a very short period of time, the singing school movement became one of the most popular vehicles of entertainment in New England, and by the closing decades of the century its popularity had swept Virginia and Pennsylvania, and surged into Atlantic Canada as well. ${ }^{1}$

Singing schools, typically, were conducted by itinerant "masters" whose coming was heralded, usually, by a newspaper advertisement or a broadside stating particulars of time, place and fee, and outlining the course of study. Instruction was given in the evenings over a period which could vary from three weeks to three months. The schools culminated, as a rule, in a grand public concert in which the neo-literates demonstrated, for the dazzlement of family and friends, their new-won ability to extract full-throated harmony from a series of marks printed on a page.

As the movement grew, the aspirations of its instigators were realized: a remarkable improvement in the standard of church singing ensued. But the burgeoning of musical literacy produced effects unforseen by the clergy. As large numbers of people acquired the ability to read music, they began to clamour for music to read. This need was met, in part, by importing a wide variety of tunes from England and publishing them in American collections compiled, more often than not, by singing masters. Typically, these tune-books were oblong, their width greater than their height - "end-openers" or "long-boys" they were dubbed; they contained an introductory section giving instruction, often very detailed, in the art of music, followed by a body of tunes in the various metres used in hymn and versified psalms. Some compilers developed unconventional systems of notation to smooth the path to sight-singing. As early as 1761, a trickle of original American compositions began to find their way into tunebooks. In that year, James Lyon published his Urania in Philadelphia, including, in the company of ninety tunes gathered from English sources, six of his own.

${ }^{1}$ See Helmut Kallmann, A History of Music in Canada 1534-1914 (Toronto: University of Toronto Press, 1960), pp, 52-53. 
Before the end of the decade, the trickle had become a flood. Psalm tunes, hymn tunes, set-pieces and anthems, many in the "fuging tune" style which became their hallmark, flowed from the pens of a stout new breed of "tune-smiths" America's first generation of composers. ${ }^{2}$

Over the past few decades music historians in the United States have discovered in the tune-books compiled by these largely self-taught craftsmen a particularly rich source of musical tradition which continues to find expression in both vernacular and cultivated musics. To a speculative curiosity aroused by reading Irving Lowens, Allen Britton, Richard Crawford and other scholars on tune-books in the United States, my personal interest in the scope and nature of analogous Canadian publications owes its motivation. To the delay in satisfaction of that curiosity caused by inaccessability of the materials, the first published fruit of an interest by now over four years old owes its present form. Tune-books published in early Canada simply had not been brought together as a body of literature: surviving copies were widely scattered; unknown titles were difficult to locate by conventional bibliographic tools and, as it turned out, some of the best examples appeared on no list at all. The present bibliography locates all the items of which I am aware and describes at least one copy of every issue seen. The notes emphasize Canadian content.

The study is arranged in two parts. The first lists briefly, in chronological order, all the publications in all the impressions and editions I know of. The second is the bibliographical description. Tune-books are listed alphabetically by surname of the compiler when he is mentioned on the title page, and by the first significant word of the title when the compiler is not identified. Descriptive conventions used in quasi-facsimile transcription, collational formula, technical features, and contents are based on Philip Gaskell, $A$ New Introduction to Bibliography (Oxford: Clarendon Press, 1974), pp. 328-335. Some inconsistency in the level of description (particularly of collation) has resulted from various circumstances - a combination of factors usually: deterioration of the book, tightness of the binding, shortness of time in a library far from home. . . . Nevertheless, most of the volumes are fully described.

The study in hand must not be taken as definitive; it is a preliminary statement only. But it is, probably, a fairly full statement - full enough to be of use as a guide to materials of the Canadian heritage which have been neglected far too long. It is offered for publication now in the hope of generating among bibliographers, musicologists, and others, the kind of interest which will produce the information needed to make the statement complete: information about other titles, undiscovered editions, the printers (as distinct from the publishers), the compilers - Alexander Davidson, for example, whose Sacred Harmony in thou-

${ }^{2}$ The above sketch is only the barest outline of a topic treated in some detail in most of the readily-available general histories of American music. An excellent overview is found in H. Wiley Hitchcock's Music in the United States: A Historical Introduction, $2 \mathrm{~d}$ ed. (Englewood Cliffs, N.J.: Prentice Hall, 1974), pp. 1-22. A fuller, thoroughly readable account is Robert Stevenson's Protestant Church Music in America (New York: Norton, 1966), pp. 12-90. Those who would plunge fully into the New England tune-book/singing school ethos will find the biography of the movement's most seminal figure very rewarding: David P. McKay and Richard Crawford, William Billings of Boston (Princeton: Princeton University Press, 1975). 
sands of copies served Upper Canadian Methodists for a quarter-century, has disappeared with hardly a trace; who was he? - examples of shape or numeral notation, positive links between specific tune-books and particular congregations or singing societies. ... Readers who are able to contribute information, or who wish to comment on the bibliography as it stands, are invited to communicate with the author (1210 Prince of Wales Drive, Ottawa, Ontario K2C 1M9).

\section{CHRONOLOGY}

1801 Humbert, Stephen. Union Harmony. St. John, N.B. [No known surviving copy.]

1816
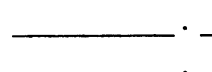
, 2 d ed., St. John, N.B. , $2 \mathrm{~d}$ ed. A later state.

1821 Jenkins, George. A Selection from the Psalms of David. Montreal.

183- The Harmonicon, 1 st ed. No copy located.

1831 Humbert, Stephen. Union Harmony, 3d ed. St. John, N.B.

1832 Burnham, Mark. Colonial Harmonist. Port Hope, U.C.

1835 Estey, Zebulon. New Brunswick Church Harmony. St. John, N.B. Warren, William. A Selection of Psalms and Hymns. Toronto.

1838 Davidson, Alexander. Sacred Harmony. Toronto.

1840 Humbert, Stephen. Union Harmony, 4th ed. St. John, N.B.

1841 The Harmonicon, $2 \mathrm{~d}$ ed. Pictou, N.S.

1845 Clarke, J.P. Canadian Church Psalmody.

1845 Davidson, Alexander. Sacred Harmony.... with a Supplement. Toronto.

The Presbyterian Psalmody. Montreal. [Shape note edition.] Toronto. The Harmonicon, $3 \mathrm{~d}$ ed. Pictou, N.S.

1861 Fripp, H.R. Church Hymn Tunes, Chants and Responses. Toronto.

1862 Chants Evangéliques. Montreal.

1863 Everett, Lemuel C. The Canadian Warbler. Toronto and Montreal.

1864 The Canadian Church Harmonist. Toronto. . A later state.

1865? Linton, George. The Vocalist. Toronto.

1866 The Canadian Church Harmonist. Toronto.

The Canadian Sunday School Harp. Toronto.

1866? Linton, George. The Union Chimes. Toronto. 


\section{DESCRIPTIVE BIBLIOGRAPHY}

BURNHAM, Mark. Colonial Harmonist. Port Hope, U.C., 1832.

Copy Described: McGill/Lande.

Title.

[Within an ornamental frame, $12.1 \times 20.8 \mathrm{~cm}$.] COLONIAL HARMONIST | BEING A COMPILATION OF THE | MOST APPROVED TUNES, AN=* THEMS, AND CHANTS. I [Gothic] With a Figured Bass for the Organ and Piano Forte. I DESIIGNED FOR ALL DENOMINATIONS OF CHRISTIANS. I [4.6 cm. rule] I SELECTED AND ARRANGED BY MARK BURNHAM. I [4.6 cm. rule] I PORT HOPE, U.C. I PUBLISHED BY THE COMPILER. I 1832.

\section{Collation.}

$\mathrm{A}^{4} \mathrm{~A}^{2}-\mathrm{Y}^{4} \mathrm{Y}^{2}$; [ $\$ 1$ signed]; 144 leaves, pp. $1-5$ 6-15 $16-17$ 18-228 (misprinting 213 as ' 123 ', 228 as ' 128 ') [ [=228]

Technical Notes.

Signatures: Invariably in the left hand margin about the centre of the page, the letters and numerals rotated counterclockwise through $90^{\circ}$.

Printing Process. The music is printed from individual types, $123 \times 207 \mathrm{~mm}$. (p. 63).

Paper: Leaf size 13.7 x 23.7; no marks, smooth, white.

Contents. 1 title, 2 blank; 3 Advertisement, 4 Introduction, 5-15 Rudiments to the Art of Singing, 16 Explanation of Musical Terms, 17-286 Music, 287 Alphabetical Index, 288 Metrical Index.

Notes.

Burnham's Colonial Harmonist is the earliest tune-book published in Upper Canada of which any record has been found. It is a true tune book in that the words of one stanza only of the psalm or hymn are given with the music; the tunes, however, are not keyed to any specific hymn or psalm collection. The Colonial Harmonist exhibits all the marks of the American tune-book: shape, repertoire, theoretical introduction to music, and original composition. The Rudiments are a version of those published by the Boston Handel and Haydn Society of Church Music. Six tunes are ascribed to the compiler: Resurrection L.M., 37; Hermitage C.M., 67, Cobourg S.M., 141; Dunbarton H.M., 178; Nelson S.M., 184; and Goffstown 8's \& 7's, 194. Kingston C.M., 89 and Port Hope C.M., 95, may also be Burnham's work or that of some other local composer. Quebec Chapel L.M., 40, Canada L.P.M., 77, and Niagara C.M., 86, may also be local compositions, but not necessarily, since the places commemorated in the titles often inspired the imagination of persons outside the country. The music is mainly in four parts and printed in open score. A figured bass is provided for the use of the keyboard accompanist.

Other Copies: McGill (Rare Books); Newberry, Chicago.

*The sign = indicates a hyphen not in the original. 
CANADIAN CHURCH HARMONIST. 1864.

Copy Described: Massey College, Toronto.

Title.

THE CANADIAN I CHURCH HARMONIST: I A COLLECTION OF SACRED MUSIC, I CONSISTING OF A CHOICE SELECTION OF I PSALM AND HYMN TUNES, ANTHEMS, INTROITS, SENTENCES, \&c., I FROM THE WORKS OF I [Gothic] Handel, Haydn, Mozart, Fawcett, Leach, Clark, Jackson, Mason, and other Celebrated Composers. I CAREFULLY SELECTED AND COMPILED | BY A COMMITTEE. | [5.2 cm. rule] | "Venite exultemus Domino." - Psalm xcv. | [5.2 cm. rule] | [Printer's device $-5.8 \mathrm{~cm}$. decorated rule] | Toronto I Published by ANSON GREEN, Wesleyan Book Room, I No. 80 King Street East. I 1864.

Collation.

In 8s: $\pi^{8}$ A-G $\mathrm{G}^{8} H^{8} \mathrm{I}^{8} \mathrm{~J}-\mathrm{U}^{8} \chi^{8}$; [\$ 1 signed] ; 184 leaves, pp. [2], $i-v$ vi-xix $x x 21$ 22-348 349-362, [4] [=2, 20, 342, 4].

Technical Notes.

Signatures: The following irregularities are noted. $\pi 6$ is signed with a 2; A2 is signed with a 3 .

Printing Process: The music is engraved, $123 \times 203 \mathrm{~mm}$. (p. 207).

Paper: Leaf size 15.4 x $23.7 \mathrm{~cm}$.; no marks, smooth, white.

\section{Contents.}

$\pi 1^{\mathrm{r}}-\pi 1^{\mathrm{v}}$ blank, $i$ title, ii blank, iii Preface, $i v$ blank, $v$-xix Introduction to the Science of Music, $x x$ Explanation of Musical Terms, $21-348$ music, 349-351 Alphabetical Index to the Tunes, 351 [Index to the] Anthems, \&c., 352-353 Metrical Index, 354-361 General Index to the Hymns and Tunes, 362 blank, $\chi^{\mathrm{r}}-\chi^{\mathrm{V}}$ blank.

Notes.

The Canadian Church Harmonist is the second tune-book published by the Methodists of Upper Canada (Canada West, in 1864); it replaced Alexander Davidson's Sacred Harmony, first issued in 1838. Its emphasis on the music of the great composers of Europe and the "scientific" composers of the United States reflects the growing affluence and respectability of Canadian Methodism. Not surprisingly, the work contains only three pieces which may have been the work of local musicians: [J.P.?] Clarke's Port Hope L.M., 61; Toronto C.M., 86, and T. Clark's Canada L.M., 56. The Introduction to the Science of Music is essentially the same as the Elements of Vocal Music, pp. iv-xxiv, in The Harmonicon $3 \mathrm{~d}$ ed. (Pictou, N.S. 1855), which acknowledges the source to be the Boston Academy's Collection of Church Music [p. iv]. The words of the first verse only are given with each tune, and the music is keyed to the Methodist hymn book. The music is in four parts which are set in open score.

Other Copies: Metropolitan Toronto Central Library/Baldwin Room.

CANADIAN CHURCH HARMONIST. Another state.

Copy described: Massey College, Toronto.

Title. 
THE CANADIAN I CHURCH HARMONIST: I A COLLECTION OF SACRED MUSIC, I CONSISTING OF A CHOICE SELECTION OF I PSALM AND HYMN TUNES, ANTHEMS, INTROITS, SENTENCES, \&c., I FROM THE WORKS OF I [Gothic] Handel, Haydn, Mozart, Fawcett, Leach, Clark, Jackson, Mason, and other Celebrated Composers. I CAREFULLY SELECTED AND COMPILED | BY A COMMITTEE. | [5.2 cm. rule] | "Venite exultemus Domino." - Psalm xcv. I [5.2 cm. rule] I [Printer's device $-5.8 \mathrm{~cm}$. decorated rule] I Toronto I PUBLISHED BY SAMUEL ROSE, WESLEYAN BOOK ROOM, I NO. 80 KING STREET EAST.

\section{Collation.}

$\pi^{8} \mathrm{~A}^{8} B-C^{8} \mathrm{D}-\mathrm{F}^{8} G-H^{8} \mathrm{I}^{8} \mathrm{~J}-\mathrm{S}^{8} T^{8} \mathrm{U}^{8} \chi^{6} ;$ [\$1 signed]; 182 leaves, pp. [2] , $i-v$ vi-xi $x i i$ xiii-xv $x v i$ xvii-xix $x x, 2122-348349-362[=2,20,342]$.

Technical Notes.

Signatures: The following irregularities are noted. 6 is signed with a 2; A2 is signed with a 3 .

Printing Process: The music is engraved, 123 x $203 \mathrm{~mm}$. (-. 207).

Paper: Leaf size 15.4 x $23.7 \mathrm{~cm}$.; no marks, smooth, white.

\section{Contents.}

$\pi 1^{\mathrm{r}}-\pi 1^{\mathrm{V}}$ blank, $i$ title, ii blank, iii Preface, $i v$ blank, $v$-xix Introduction to the Science of Music, $x x$ Explanation of Musical Terms, $21-348$ music, 349-351 Alphabetical Index to the Tunes, 351 [Index to the] Anthems, \&c., 352-353 Metrical Index, 354-361 General Index to the Hymns and Tunes, 362 blank.

Notes.

Besides the publisher's statement on the title page, the only difference of substance between this volume and the one described above is the first page of music, p. 21. Both the words and music have been completely reset. The most obvious difference is the elaborate time signature symbol which clashes with the uniform simplicity found elsewhere in the book. This state appears to have been made from the same plates and type as the above. However, the much greater incidence of worn, broken, and missing type suggests that it is the later impression of the two, a suggestion strengthened by the fact that every instance of broken type observed in the first volume is also found in the second.

CANADIAN CHURCH HARMONIST. 1866.

Copy Described: McGill/Lande.

Title.

The title page of this impression is the same in every detail as the second copy described above, with the exception that a final line is added giving the date: 1866 .

Notes.

No substantive differences between the contents of this impression and the other two were observed. This was the first copy seen; it must now be examined again, in the light of the differences which emerged in the page-by-page examination of the Massey College examples, in order to establish chronological precedence. 
CANADIAN SUNDAY SCHOOL HARP. [Dated in Preface, 1866] . Copy Described: Metropolitan Toronto Central Library/Baldwin Room.

Title.

THE I CANADIAN I SUNDAY SCHOOL HARP. [Arched] I $[3.9 \mathrm{~cm}$. decorated rule] | HYMNS AND TUNES | FOR I SUNDAY SCHOOLS AND THE SOCIAL CIRCLE. | [3.2 cm. decorated rule] | TORONTO: | PUB= LISHED BY SAMUEL ROSE, WESLEYAN BOOK ROOM.

\section{Collation.}

In 8s: $1^{8} \quad 2-8^{8} 9^{8} 10^{8} 11-13^{8}$; [ 1 signed] ; 104 leaves, pp. $12-112113$ $114-202203204-205$ [3] [=205, 3] .

Technical Notes.

Printing Process: The music is engraved, $99 \times 150 \mathrm{~mm}$. (p. 13).

Paper: Leaf size, $12.1 \times 18.7 \mathrm{~cm}$.; no marks, smooth, white.

Contents.

1 title, 2 Preface, 3-202 music, 203-205 Index to Hymns and Tunes, 3 blank pages.

Notes.

This is a hymn book with tunes; the words of all verses are given, one or more between the music staves, the others printed nearby in verse form. The one singularly Canadian feature of the collection is the hymn on p. 170, The Canadian Boat Hymn with words by the Rev. T. Savage, set to the famous tune normally associated with Thomas Moore's Canadian Boat Song. The tunes are harmonized, mostly in four parts, and the music is printed on two staves.

Other Copies: Massey College, Toronto.

CHANTS EVANGELIQUES. Montréal, 1862.

Copy Described: United Church Archives, Toronto.

Title.

CHANTS ÉVANGÉLIQUES I, POUR I LE CULTE PUBLIC I ET POUR | L'ÉDIFICATION PARTICULIÉRE, | A | L'USAGE DES ÉGLISES | DU | CANADA, I AVEC MUSSIQUE A QUATRE PARTIES. I [1.5 cm. decorated rule] I Je chanterai à l'Éternel durant ma vie; je psalmodierai à mon Dieu pen= dant que | j'existerai. - Psaume 104:33. | [3.4 cm. printer's device] $\mid$ MON= TRÉAL: | IMPRIMÉ PAR JOHN LOVELL. $\mid 1862$.

\section{Collation.}

In 4s: $1^{4} 2-25^{4}$ [\$1 signed] ; 100 leaves, pp. [2], $12-198[=2,198]$.

Technical Notes.

Printing Process: The music is engraved, $145 \times 83 \mathrm{~mm}$. (p. 18).

Paper: Leaf size 17.1 x $11.4 \mathrm{~cm}$., no marks, smooth white.

\section{Contents.}

$I^{\mathrm{r}}$ title, $I^{\mathrm{V}}$ Preface, pp. 1-194 music, 195 Table des matières, 196-197 Table alphabétique, 198 Table des autheurs des cantiques desquels nous avons appris les noms. 
Notes.

The collection of hymns with music appearing under the title Chants Evangéliques has been the most enduring of all the works examined. French-Canadian protestant congregations still sing from subsequent editions which have changed little over the years. The preface mentions a smaller collection of the same name published in New York [New York Public Library has a copy dated 1847], but suggests that it is not adequate to fully serve congregational needs since it contains no hymns for Holy Communion, Marriage, Baptism, nor for Sunday Schools defects which the compilers of the new collection aim to remedy. When hymns from the earlier volume are retained in the new, their number in the old is given in brackets. The copy examined appears to be the first edition, since the date of publication (1862) coincides with that of the preface. The music of Chants Evangéliques is in four parts and set in close score. It contains no material of obviously Canadian origin.

Other Copies: Acadia University.

CLARKE, James Paton. Canadian Church Psalmody. Toronto, C.W., 1845. Copy Described: University of Toronto.

Title.

UNDER THE SANCTION OF I THE HONOURABLE AND RIGHT REV= EREND THE LORD BISHOP OF TORONTO. I [8.6 cm. double rule $]$ CANADIAN CHURCH PSALMODY: I CONSISTING OF I [Gothic] Psalm Tunes, Chants, Anthems, \&c. I WITH I INTRODUCTORY LESSONS AND EXERCISES IN SACRED MUSIC. I [4.7 cm. rule] I EDITED BY J.P. CLARKE, I ORGANIST OF CHRIST CHURCH, HAMILTON. I [4.7 cm. rule] 1 Entered according to Act of the Provincial Legislature, in the year of Our Lord One Thousand Eight Hundred and Forty-Five, by JAMES PATON CLARKE, in the office of $\mid$ the Registrar of the Province of Canada. I [6.3 cm. double rule] I TORONTO: I H. \& W. ROWSELL, KING STREET. I FOR SALE ALSO AT THE DEPOSITORY OF THE CHURCH SOCIETY, TORONTO; BY RAMSAY, ARMOUR \& CO., KINGSTON; I GOODEVE \& CORRIGAL COBOURG; RAMSAY \& MACKENDRICK, HAMILTON; J.F. ROGERS, WOODSTOCK; I ARMOUR \& RAMSAY, AND J. WALTON, MONTREAL. I [ $.9 \mathrm{~cm}$. rule $]$ | 1845 .

\section{Collation.}

In 2s: $\pi^{2} A-I^{2} \mathrm{~J}-2 \mathrm{D}^{2} ;$ [ $\$ 1$ signed] ; 58 leaves, pp. $i-i v$ v-viii. 1-108 [=8, 108].

Technical Notes.

Printing Process: The music is engraved, $175 \times 245 \mathrm{~mm}$. (p. 2).

Paper: Leaf size 21.3 x $29.6 \mathrm{~cm}$; ; no marks, smooth, white.

\section{Contents.}

$i$ title, $i i$ [at bottom of page, between $5.5 \mathrm{~cm}$. rules] ROWSELLS AND THOMPSON, PRINTERS, KING STREET, TORONTO., iii Table of Contents, iv-viii Introductory Lessons and Exercises, 1-108 music. 
Notes.

Canadian Church Psalmody is a psalm book with music. Although it shares a good deal of repertoire with American tune-books of the day, the meagerness of the collection and the narrow proportion of hymns to psalms disclose an essence which, in the mid-nineteenth century, was characteristic of English (Anglican) congregational music. The work is printed in the characteristic tunebook shape, but it is larger than those based on American models (approx. $22 \times 30 \mathrm{~cm}$. compared to, say, $14 \times 25 \mathrm{~cm}$.). The theoretical introduction covers much the same ground as contemporary American examples, but the pattern of presentation is quite distinctive; it may well be Clarke's own work. ${ }^{3}$ The compiler contributes six of his own tunes: Yarmouth C.M., p. 20; Penetence L.M., p. 34; Christ Church L.M.D., p. 40; Hamilton S.M., p. 44; Helmsley New P.M., p. 48; The Fourth Hymn P.M., p. 66. There are three chants by Clarke, as well: Trisagion (No. 2), p. 70; Te Deum (No. 2), p. 99; Te Deum (No. 3), p. 103. The music is in four or five parts - the treble and bass voices, together with the organ accompaniment, on the bottom two staves, the remaining parts set above, one part to a stave.

Other Copies: Anglican Church Archives, Toronto; McGill/Lande; University of Western Ontario; National Library of Canada.

DAVIDSON, Alexander. Sacred Harmony. Toronto, U.C., 1838.

Copy Described: United Church Archives, Toronto.

Title.

SACRED HARMONY: I CONSISTING OF । [A] VARIETY OF TUNES, ADAPTED TO THE DIFFERENT METRES IN THE I WESLEYAN METHOD= IST HYMN BOOK, I AND A FEW I ANTHEMS AND FAVOURITE PIECES; I SELECTED FROM THE MOST APPROVED AUTHORS, ANCIENT AND MODERN, I UNDER THE DIRECTION OF THE CONFERENCE OF THE WESLEYAN-METHODIST CHURCH IN CANADA, I BY ALEXANDER DAVIDSON. I [2.1 cm. rule] I "They sing the Lamb in Hymns above, I And we in Hymns below." I [1 cm. printer's device] I TORONTO, U.C. I PUB= LISHED BY JOHN RYERSON, AT THE CONFERENCE OFFICE, 4, TORONTO STREET. I JOSEPH H. LAWRENCE, PRINTER. I [.6 cm. rule] I 1838.

\section{Collation.}

In 4s: $\pi^{8}$ A1 2-[B3 4 etc.]-32 ; [\$1 signed]; 136 leaves, pp. $i$-iii iv $v$ vi-xvi; 1 2-250 $251252-256$ (misprinting 235 for 231) [=16, 256].

Technical Notes.

Printing Process: The music is engraved, $123 \times 196 \mathrm{~mm}$. (p. 220).

Paper: Leaf size: 14 x 22.2 cm.; no marks, smooth white.

${ }^{3}$ Clarke was the first Bachelor of Music graduated at the University of Toronto where he eventually became a professor. See Helmut Kallmann, "James Paton Clarke - Canada's First Mus. Bac." The Canada Music Book I (1970): 41-53. 


\section{Contents.}

$i$ title, $i i$ blank, $i i i$-iv Preface, $\nu$-xiv Introduction to the Science of Music, $\mathrm{xv}$ Explanation of Musical Terms, xvi blank, 1-250 music, 251-253 Alphabetical Index, 253 [Index to] Anthems and Pieces, 254-255 Metrical Index, 256 blank.

Notes.

Sacred Harmony was the first Methodist tune-book published in Upper Canada. Although it is keyed to John Wesley's Hymns for the Use of the People Called Methodists, the words of all the verses are printed beside the music, which makes the publication more properly a hymn book with music. The "Introduction to the Science of Music", following a common American fornula, is a catechism. Several of Davidson's original compositions, or those of other local composers are included: Belleville C.M., p. 50; Port Hope L.M., p. 72; Toronto L.M., p. 83; Belleville 48's x 26's, p. 156; Prescott S.M., p. 112; Cobourg 8 lines 8's \& 7's; and (possibly) Niagara P.M., p. 228. The music is in three and four parts, printed in open score.

Other Copies: None located. . Sacred Harmony. . . With a Supplement. Toronto, C.W., 1845. Copy Described: Acadia University.

Title.

SACRED HARMONY: I CONSISTING OF I A VARIETY OF TUNES, I ADAPTED TO THE DIFFERENT METRES IN THE WESLEYAN-METHODIST HYMN BOOK; I AND A FEW I ANTHEMS AND FAVOURITE PIECES; I [Gothic] Selected from the most approved Authors, Ancient and Modern, I UNDER THE DIRECTION OF THE CONFERENCE OF THE WESLEYANMETHODIST CHURCH IN CANADA. I BY ALEXANDER DAVIDSON. I "They sing the Lamb in Hymns above, I And we in Hymns below." I [ $2.8 \mathrm{~cm}$. printer's device] । WITH A SUPPLEMENT. I [2.7 cm. printer's device] I TORONTO: I PUBLISHED BY ANSON GREEN, CONFERENCE OFFICE, I No. 9, WELLINGTON BUILDINGS, KING STREET. I 1845.

Title of Supplement.

SUPPLEMENT | TO THE I SACRED HARMONY: I CONSISTING OF A CHOICE SELECTION OF I HYMN TUNES, SENTENCES, AND ANTHEMS, I SELECTED FROM THE I COMPOSITIONS OF HANDEL, HAYDN, MOZART, BEETHOVEN, WEBER AND OTHERS, I INCLUDING I THE ELEMENTARY INSTRUCTION, ON THE SYSTEM OF PESTALOZZI, I [Gothic] As adopted by the Boston Academy of Music. I PREPARED BY ORDER OF, AND AP= PROVED BY, A COMMITTEE APPOINTED FOR THAT PURPOSE.

\section{Collation.}

Time available for the examination was very limited. The format is essentially the same as the 1858 copy described below, but there are some irregularities, and several pages are missing.

Technical Notes.

Printing Process: The music is engraved, $124 \times 196 \mathrm{~mm}$. (p. 125).

Paper: 14.1 x $22.4 \mathrm{~cm}$., no marks, smooth, white. 


\section{Contents.}

$1^{\mathrm{r}}$ blank, $I^{\mathrm{V}}$ blank, $i$ title, $i i$ [3.2 cm. printer's device] । J. H. LAWRENCE, । PRINTER. I $[3.1 \mathrm{~cm}$. printer's device], iii-iv Preface, $v$-xix Introduction to the Science of Music, $x x$ Explanation of Musical Terms, 1-250 music, 251 title to Supplement, 252 blank, 255-338 music, [missing 339-346] , 347 end of Metrical Index, [Index to] Anthems and Pieces, 348 blank, [2 blank] .

Notes.

The music and text of this edition, as far as page 250, appear to be the same as those of the 1838 collection. The Supplement which follows contains no new Canadian material.

Other Copies: None located.

Sacred Harmony. . . With a Supplement. Toronto C.W., 1848.

Copy Described: Newberry Library, Chicago.

Title.

SACRED HARMONY: | CONSISTING OF I A VARIETY OF TUNES, I ADAPTED TO THE DIFFERENT METRES IN THE WESLEYAN-METHODIST HYMN BOOK; I AND A FEW I ANTHEMS AND FAVOURITE PIECES; I [Gothic] Selected from the most approved Authors, Ancient and Modern, I UNDER THE DIRECTION OF THE CONFERENCE OF THE WESLEYANMETHODIST CHURCH IN CANADA. I BY ALEXANDER DAVIDSON. I "They sing the LAMB in Hymns above, I And we in Hymns below." । [2.7 cm. printers device] I TORONTO: I PUBLISHED BY ANSON GREEN, AT THE CONFERENCE OFFICE. I No. 9, WELLINGTON BUILDINGS, KING STREET. | 1848 .

\section{Notes.}

Early Toronto's Methodist newspaper, The Christian Guardian of March 7th, 1838, three weeks before the publication of Sacred Harmony's first edition, announced the availability of two styles of music print: "Two impressions will be worked off - one in round, and the other in patent notes." Patent notes, or "shape notes", used four distinctive shapes as an aid to sight-singers. With the exception of the "Introduction to the Science of Music" which is modified to demonstrate the shape note system, and the appearance of the notes themselves, the literary and musical contents appear to coincide with the 1845 and 1858 printings.

This is an exceptionally scarce piece of Canadian musicalia - the only example of shape note publication found in the course of the present study. Advertisements in the Guardian over the quarter century that Sacred Harmony remained in print suggest that all editions were available in either system of notation. The search for copies is hampered by the fact that volumes reported to the National Union Catalog: pre-1956 Imprints are filed under "Wesleyan Methodist Church in Canada". The volumes available have not yet passed "S". The search for shape note editions is complicated further by the fact that catalogue entries usually do not differentiate between conventional and shape note issues.

Other Copies: None located. 
Sacred Harmony. . . With a Supplement. Toronto, C.W., 1858.

Copy Described: McGill/Lande.

Title.

SACRED HARMONY: I CONSISTING OF I A VARIETY OF TUNES, I ADAPTED TO THE DIFFERENT METRES IN THE WESLEYAN METHODIST HYMN-BOOK I AND A FEW I ANTHEMS AND FAVOURITE PIECES; | [Gothic] Selected from the most Approved Authors, Ancient and Modern I UNDER THE DIRECTION OF THE CONFERENCE OF THE WESLEYAN METHODIST CHURCH IN CANADA. I BY ALEXANDER DAVIDSON. I "They sing the LAMB in Hymns above, And we in Hymns below." I $[5.4 \mathrm{~cm}$. printers device] I WITH A SUPPLEMENT. I [5.4 cm. printers device] I [Gothic] Toronto: I PUBLISHED BY G.R. SANDERSON, AT THE CONFER= ENCE OFFICE, I No. 9 WELLINGTON BUILDINGS, KING STREET. I 1858.

\section{Collation.}

In 4s: $1^{4} 2^{4} 3^{4}\left(-3_{2,3}\right)$ A 2 - [B3 4 etc.] -Q31 $31^{4}\left(-32_{2,3}\right) 33-44^{4}$; [ $\$ 1$ signed] ; 184 leaves, pp. [2] $i$-iii iv $v$ vi-xix $x x \quad 1-250255256-342343344$ $345346-347348$ [2] [2, 20, 344, 2].

Technical Notes.

Printing Process: The music is engraved, 124 x $199 \mathrm{~mm}$.

Paper: Leaf size 14.1 x $22.4 \mathrm{~cm}$., no marks, smooth, white.

Contents.

$1^{\mathrm{r}}$ blank, $1^{\mathrm{V}}$ blank, $i$ title, ii blank, iii -iv Preface, $v$-xix Introduction to the Science of Music, xx Explanation of Musical Terms, 1-250 music, 255-342 Supplement, 343-344 Alphabetical Index, 345-347 Metrical Index, 347 [Index to] Anthems and Pieces, 348 blank, [2 blank].

Notes.

The contents appear identical to those of the 1845 printing, except that there is no title page to the Supplement. The signature in which it should appear, no. 32 , is two leaves short. The second leaf is absent from the 1845 copy also. The numbers 353-354 which should appear on that leaf are omitted from the pagination sequence of both volumes. The complete text, however, seems to be present, since the index includes no reference to those pages.

Other Copies: Queen's University.

ESTEY, Zebulon. New Brunswick Church Harmony. St. John N.B., 1835. Location: Newberry, Chicago.

Title.

Missing. The handwritten sheet which gives the title and a biographical sketch of the composer is transcribed here. It is inserted at the front of the seriously mutilated copy examined.

[In cursive hand] New Brunswick Church Harmony/ I By Deacon Zebulon/ Estey, St. John NB. 1835. I 282 pp. I Mr. Estey, son of Thomas, was born at Gagetown, Queens Co. I NB. Dec 27, 1806. m Maria Lamb 1831, \& had 5 sons 
3 daus $\mid$ all engaged in mercantile pursuits in St John NB. I He was an excellent singer, led the choir in I Germain St Bap Ch many years from 1824, when he was 18. I \& then in the Brussels St Bap. Ch. He d. Dec 22. 1864.I He was a deacon. \& Sup of Sun Schs. as well as chorister. I His widow, b. 1810, still lives.

Notes.

Estey's New Brunswick Church Harmony draws its repertoire from the contemporary American treasury. One, possibly two tunes, may be his own:Zebulon, p. 126, and Martha, p. 127. The most noteworthy feature of the collection is Estey's inclusion of sixteen pages of music - mainly extended pieces - by his contemporary and fellow resident of St. John, Stephen Humbert. He selects Jessop's Lamentation, pp. 71-72; Free Grace, P.M., pp. 77-78; Hail to the Day Spring, pp. 84-90; and Waterloo, p. 91-95. The music, three and four parts in open score, is set in individual types.

Other Copies: L.S. Loomer of Windsor, N.S. has a copy in his private collection. Its title page reads: [within an ornamental frame $19.9 \times 12.6 \mathrm{~cm}$.] NEW BRUNS= WICK | CHURCH HARMONY | COLLECTION I FROM [Gothic to end of line] A [p] proved English and American Authors. I [1.3 cm. rule] I BY ZEBULON ESTEY. | [1.3 cm. rule] | SAINT JOHN, (N.B.) | [T] HE WHOLESALE AND THE RETAIL, BY BLAKSLEE \& ESTEY.। NORTH MARKET WHARF. | [.6 cm. rule] | 1835 .

Note.

The elements which make up the decorative frame seen in this copy of Estey's work are the same as those used in the fourth edition of Stephen Humbert's Union Harmony (1840).

EVERETT, L.C. The Canadian Warbler. Toronto, Montreal, 1863.

Copy Described: Metropolitan Toronto Central Library/Baldwin Room.

Title.

[Superimposed on a naturalistic maple leaf, $8.3 \times 8.3 \mathrm{~cm}$.] THE | CANA= DIAN [arched] I WARBLER I A I NEW COLLECTION । OF I HYMNS \& TUNES I FOR I SABBATH SCHOOLS. I BY L.C. EVERETT. I [below leaf] PUBLISHED BY A. \& S. NORDHEIMER, I TORONTO AND MON= TREAL. I 1863.

\section{Collation.}

12 -192 [=192].

Technical Notes.

Printing Process: The music is engraved, $92 \times 116 \mathrm{~mm}$. (p. 117).

Paper: Leaf size 11.3 x $14 \mathrm{~cm}$., no marks, smooth, white.

Contents.

1 title, 2 Notice [of copyright], 3 Preface, 4-188 music, 189-190 Alphabetical Index, 191-192 Index of First Lines.

Notes.

The Canadian Warbler is a collection of hymns with tunes. The compiler, Lemuel C. Everett, was an American composer, trained in Boston and Leipzig, 
who with his brother Dr. A.B. Everett gained fame as a teacher of vocal music in the Southern and Middle Atlantic States. ${ }^{4}$ The Warbler contains a large number of the tunes of both brothers as well as some by another American, George W. Linton, who also published in Canada (The Vocalist, 1867). Several of the compiler's tunes appear to have been composed in Canada, since dates and locations in Canada West are given with the titles: Blessings of the Sabbath School, No.27, Brantford, C.W., Nov. 10, 1861; We Speak of the Realms, No. 34, Toronto, C.W., March 15th, 1862; and Praise to Christ, No. 154, Toronto, C.W., Feb. 1, 1862. The music is mainly in four parts set in close score. Some pieces have an additional superior staff for a soloist or unison chorus.

Other Copies: None located.

FRIPP, H.R. Church Hymn Tunes Chants and Responses. Toronto, C.W., 1861. Copy Described: Acadia University.

Title.

CHURCH I [Gothic] Hymn Tunes, Chants and Responses, I FOR THE I SEVERAL SEASONS OF THE CHRISTIAN YEAR, I AS SUNG IN I. THE CHURCH OF THE HOLY TRINITY, TORONTO. I SELECTED AND EDITED I [Gothic] Under the Sanction of the Clergy, I BY | H.R. FRIPP, ORGANIST AND CHOIR-MASTER. I Printed for the use of the Congregation. I [2.3 cm. printers device] I [Gothic] Toronto; I PRINTED AT THE "GUARDIAN" STEAM PRESS. | 1861. | [6 cm. rule] I For Sale by H. Rowsell.

\section{Collation.}

In 4s: $\left[\begin{array}{ll}1-7^{4} & 8^{2}\end{array}\right] ; 30$ leaves, pp. 1-3 4-58 59-60 [=60].

Technical Notes.

Printing Process: The music is set in individual types, 137 x $98 \mathrm{~mm}$. (p. 40). Paper: Leaf size $13.5 \times 20 \mathrm{~cm}$.; no marks, smooth, white.

\section{Contents.}

1 title, 2 blank, 3-58 music, 59 Table of Hymns in the New "Church Hymn Book", 60 [Table of] Chants.

Notes.

This tune-book is the only one encountered which was destined for the use of one congregation only. Although the tunes are drawn from the familiar repertoire, the customary tune names are missing; only the metre is given. They are harmonized in four parts and set in close score. No hymn verses are supplied.

Other Copies: None located.

${ }^{4}$ See J.H. Hall, Biography of Gospel Song and Hymn Writers (New York: AMS Press, 1971 [1914]), pp. 97-100. 
HARMONICON. 1st ed. No copy located.

HARMONICON. 2d. ed. Pictou, N.S., 1841.

Copy Described: University of Toronto.

Title.

[within a border $12.7 \times 21.7 \mathrm{~cm}$.] THE | HARMONICON: | A COLLEC= TION OF I SACRED MUSIC, I CONSISTING OF I Psalm and Hymn Tunes, Anthems, \&c., Selected from the best Authors; I WITH A COPIOUS INTRO= DUCTION TO VOCAL MUSIC. I SECOND EDITION, IMPROVED AND ENLARGED. I [4.2 cm. printers device] | PICTOU, I PUBLISHED BY JAMES DAWSON, BOOKSELLER. I 1841.

\section{Collation.}

In 4s: $1^{4} 2-9^{4} 10^{4} 11-31^{4}$ [\$1 signed]; 124 leaves, pp. 1-6 7-20 21 22-248 $[=248]$.

\section{Technical Notes.}

Printing Process: The music is set in individual types, $122 \times 214 \mathrm{~mm}$. (p. 53).

Paper: Leaf size 14.1 x 23.7; no marks, smooth, white.

\section{Contents.}

1 title, 2 blank, 3 Preface, 4-5 Alphabetical Index, 6-20 Introduction to Vocal Music, 21-248 music.

\section{Notes.}

The Harmonicon conforms closely to the pattern of contemporary American tune-books in shape, theoretical instruction, and repertoire. The collection seems not to have been the work of a single compiler, a fact which may account for the paucity of material associated with Canada. Only two Maritime place-name tunes, Fredrickton P.M., p. 179, and Amherst H.M., p. 186, reflect Canadian origin. No authorship is attributed to either tune. Fredrickton, however, a variant of Vater Unser, first published in Valentin Schumann's Gesangbuch of 1539, is claimed by Stephen Humbert who includes it in several (perhaps all) editions of his Union Harmony. Nearly all the music is in four parts, although a few tunes, like Fredrickton, are in three. The parts are displayed in open score.

Other Copies: McGill/Lande, Ottawa University.

HARMONICON. 3d. ed. Pictou, N.S., 1855.

Copy Described: United Church Archives, Toronto.

Title.

THE I HARMONICON: I A COLLECTION OF I SACRED MUSIC, I CONSISTING OF $\mid$ PSALM AND HYMN TUNES, ANTHEMS, \&c. I SELECT= ED FROM THE BEST COMPOSERS, I AND I ADAPTED TO THE USE OF THE CHURCHES IN BRITISH NORTH AMERICA. I WITH AN INTRODUC= TION TO VOCAL MUSIC. I [5.1 cm. rule] I THIRD EDITION, REVISED AND ENLARGED. । [5.1 cm. rule] I PUBLISHED BY JAMES DAWSON AND SON, PICTOU. I 1855. 


\section{Collation.}

$A^{4} \quad$ B-C $C^{4} \quad 4-10^{4} \quad 11^{4} \quad 12-19^{4} \quad 20^{4} \quad 22-23^{4} \quad 24^{4} \quad 25-30^{4} \quad 31^{4} \quad 32-34^{4} \quad\left[\begin{array}{l}\$ 1\end{array}\right.$ signed] ; 136 leaves, pp. $i$-iii iv-xxiv, 25 26-272 [24, 248].

Technical Notes.

Printing Process: Stereotype made from individual types, $126 \times 213 \mathrm{~mm}$. (p. 57). The music typography is identified on the front cover as the work of A.B. Kidder of Boston.

Paper: Leaf size 15 x $23.5 \mathrm{~cm}$; no marks, smooth, white.

\section{Contents.}

$i$ title, $i i$ Colophon statement: Entered in the Office of the Provincial Secretary, according to the Act of Assembly, I in the year 1849, by James Dawson \& Son, Booksellers, Pictou. I [2.4 cm. rule] I STEREOTYPE EDITION. I, iii Adver= tisement, iv-xxiv Elements of Vocal Music, 25-270 music, 271 Alphabetical Index, 272 Metrical Index.

Notes.

The third edition of The Harmonicon retains the same essential features as the second. The theoretical introduction has been changed, however: the "Introduction to Vocal Music" has been deleted in favour of the "Elements of Vocal Music" which are "Taken from the Boston Academy's Collection of Church Music, By Permission" [p. iv]. The publishers acknowledge the assistance of Charles Robson of Halifax and James Hepburn of Pictou in the preparation of the third edition, as well as the two earlier ones, and attribute whatever merit the collection possesses to their supervision [p. iii] Over a score of tunes which, according to the publishers, have fallen into disuse have been weeded out, and over fifty new tunes have been added. Both Canadian tunes are retained and they remain the only local material in the collection. The music remains in open score, but it has all been newly set - still in type - but the individual characters articulate with the others to produce a much smoother appearance, much closer to that produced by engraving. [cf. the two impressions of Fredrickton.]

Other Copies: Acadia University; Mount Allison University; Hector Exhibition Centre, Pictou, N.S.

HUMBERT, Stephen. Union Harmony. St. John, New Brunswick, 1801. No copy found. . Union Harmony. 2d. ed., 1816.

Copy Described: New Brunswick Museum.

Title.

[Within an ornamental frame $12.2 \times 20.6 \mathrm{~cm}$.] UNION HARMONY: I OR I BRITISH AMERICA'S SACRED VOCAL MUSICK. I FROM THE MOST AP= PROVED ENGLISH AND AMERICAN COMPOSERS, WITH SOME ORIGINAL MUSICK ON SPECIAL OCCASIONS. I TO WHICH IS PREFIXED A CONCISE INTRODUCTION. I [19.1 cm. waved rule] I While I live, will I praise the Lord: I I will sing praises unto my God, while I have any being. I 146 PSALM , 2d VERSE I [19.1 cm. waved rule] I SECOND EDITION, MUCH IMPROVED 
AND ENLARGED. I [7.1 cm. printer's device] I SAINT JOHN (New Bruns= wick:) I Published by STEPHEN HUMBERT, and sold at his Store, Market Wharf. - Sold also by MARTIN G. BLACK, Halifax: BENJAMIN \& GeORGE DEWOLF, Windsor: I and by the principal Booksellers in the BRITISH PROVINCES. I 1816. I [ $2.2 \mathrm{~cm}$. device] | C.NORRIS \& CO.PRINTERS.

\section{Collation.}

In 4s: $\mathrm{A}-\mathrm{Z}^{4} \mathrm{~A} 2-\mathrm{Q} 2^{4}$ (misprinting $\mathrm{B} 2$ as ' $\mathrm{R} 2$ '); [ $\$ 1$ signed]; 160 leaves, pp. 1-5, 6-317 (misprinting 280 as ' 082 ', 317 as ' 217 '), 318-320 [=320]

Technical Notes.

Printing Process: The music is printed from individual types, $117 \times 197 \mathrm{~mm}$. (p. 257).

Paper: Leaf size 12.7 x $22 \mathrm{~cm}$.; no marks, smooth, white.

\section{Contents.}

1 title, 2 blank, 3 Advertisement, 4 A Dictionary of Musical Terms, 5-14 Introduction to the Grounds of Musick, 15-317 Music, 318-319 Alphabetical Index, 319-320 Metrical Index.

Union Harmony. 2 d ed. 1816. Another state.

The New Brunswick Museum has two other copies, each lacking several pages. They appear identical with the perfect copy described above, except for one detail: the misprint ' 082 ' has been removed from p. 280 and replaced by the correct number. (The other error in pagination ' 217 ' for 317 remains, however, in one copy; in the other, the page is missing.) The correction suggests that, unless it was made during the run, there was more than one impression of the second edition.

Other Copies: St. John, N.B. Public Library; Nova Scotia Provincial Archives; Newberry Library, Chicago.

. Union Harmony. 3d ed. 1831.

Locations: Newberry, Yale.

Union Harmony. 4th ed. St. John, N.B., 1840.

Copy Described: National Library of Canada.

[within an ornamental frame $12.5 \times 19 \mathrm{~cm}$.] UNION HARMONY: | OR I BRITISH AMERICA'S SACRED VOCAL MUSIC. I COMPRISING A LARGE PORTION OF ANCIENT STANDARD CHURCH TUNES I IN THE VARIOUS METRES NOW IN USE. I ALSO, I MODERN EUROPEAN AND AMERICAN COMPOSITIONS I FROM THE MOST APPROVED PROFESSORS IN MUSIC: I WITH A NUMBER OF ORIGINAL TUNES OF EASY ACQUIREMENT; ANTHEMS, AND SPECIAL PIECES, I ADAPTED TO VARIOUS PUBLIC OC= CASIONS. | FOURTH EDITION, ENLARGED AND IMPROVED. $\mid[2.1 \mathrm{~cm}$. double rule, upper rule thicker] I SAINT JOHN, (New Brunswick:) | PUB= LISHED BY STEPHEN HUMBERT, AND SOLD BY HIM IN SAINT JOHN; ALSO SOLD BY WILLIAM REYNOLDS, I DAVID M'MILLAN, V.H.NELSON, AND WILLIAM AVERY, BOOKSELLERS IN SAINT JOHN. I 1840. I 


\section{Collation.}

In 4s: $1^{4} 2-42^{4} 43^{4}\left(-43_{2,3,4}\right)$ [\$1 signed] ; 169 leaves, pp. $i$-iii iv 5 6-13 $14-1516-336337338[=5,333]$.

Technical Notes.

Printing Process: The music is printed from individual types, $120 \times 202 \mathrm{~mm}$. (p. 33).

Paper: Leaf size 14 x $23.8 \mathrm{~cm}$.; no marks, smooth, white.

\section{Contents.}

$i$ title, $i i$ blank, iii-iv Preface, 5-13 Introduction to the Grounds of Music, 14 blank, 15-336 music, 337-338 Alphabetical Index.

Notes.

The first edition of Union Harmony published in 1801 was the first tunebook published in Canada. (Only one other musical publication pre-dates it: a Graduel romain issued in Quebec in $1800 .^{5}$ ) No copy is known to have survived. Union Harmony, not surprisingly, since Humbert was a loyalist, is a quintessential New England tune-book: the theoretical intorduction is obviously derivative, if not a direct borrowing; the tune repertoire is the same, and the composer has not spared his own musical outpourings. The quantity of Humbert's original work increases with each new edition after that of $1816(1831,1840)$. The fourth contains no fewer than 70 pages of his music, 21 tunes and 11 anthems, many in the "fuging" style. The tunes are: Alacrity L.M., p. 15; Truth L.M., Vivacity L.M., p. 16; Mount Calvary L.M., p. 17; Gagetown L.M., p. 43; St. John L.M., p. 45; Halifax L.M. pp. 54-55; Simplicity L.M., p. 55; Carleton Side L.M., p. 56; Activity C.M., Lively C.M., p. 89; Trial C.M., Submission C.M., p. 90; Mount Pisgah, p. 91; Singing School C.M., pp. 122-123; Remembrance P.M., p. 125; Nativity C.M., p. 127; Fredrickton 176; Remembrance P.M. (repeat), p. 200; Admiration P.M., p. 203; Sussex Vale, p. 207. Anthems are: Judah's Triumph, pp. 245-248; Mortals Awake, pp. 249-256; Trumpet, pp. 257-262; Mount Vernon, pp. 289-292; Jessop's Lamentation, pp. 293-294; Medley, pp. 297. 302; Benevolence, pp. 303-309; Herald Angels, pp. 310-313; Hail to the Day Spring, pp. 318-324; Waterloo, pp. 325-329. The music is nearly all in three parts, but some is in four. All settings are in open score.

Other Copies: New Brunswick Museum; Yale University; Newberry, Chicago.

JENKINS, George. A Selection from the Psalms of David. Montreal, U.C., 1821. Copy Described: Metropolitan Toronto Central Library/Baldwin Room.

Title.

A I SELECTION | FROM THE I PSALMS OF DAVID, I THE MUSIC (ADAPTED TO THE ORGAN AND PIANO FORTE) BY I DR. MILLER, I AND THE WORDS BY I THE REVD. GEORGE HAY DRUMMOND. I [5.8 $\mathrm{cm}$. decorated French rule] | ARRANGED I In such a manner, as to present,

${ }^{5}$ Kallmann, Helmut, Music in Canada 1534-1914 (Toronto: University of Toronto Press, 1960), p. 43. 
at one view, the Music in score for four Voices, and all the words appointed to be sung to each I Tune, as it occurs in the General Index, I BY I [Gothic] The Revd. George Jenkins, B.D. I CHAPLAIN TO HIS MAJESTY'S FORCES, I AND | EVENING LECTURER OF CHRIST CHURCH, I MONTREAL, I AND | DEDICATED, BY PERMISSION, I TO I The Right Revd. Father in God, Jacob, I LORD BISHOP I OF I QUEBEC. I [within $6.5 \mathrm{~cm}$. double rules, the outer rules, thicker] I "It is good to Sing praises to our God," Ps. 147. I [2.3 cm. printers device] I Montreal, (Lower Canada,) I PRINTED BY WILLIAM GRAY, I 1821.

Collation.

$\pi^{2}(-\pi 2) 2 \pi^{2} A-B^{2}$ C-M $M^{2}$ [\$1 signed]; 27 leaves, pp. [7] 1-46 [1] [=7, $46,1]$.

Technical Notes.

Signature position: p. 16 the, 28 itself.

Type: 230 x $90 \mathrm{~mm}$. (p. 15); roman 108; 34 lines. No page is typical. All text is verse; format and spacing varies; some pages are in double columns.

Plates: The music is "Engraved and Printed by T.G. Preston Montreal" (pl. 1). Plate dimensions $233 \times 165 \mathrm{~mm}$. (plate no. 31). Plates are inserted between leaves 1 and 2 of each gathering, A-K and between gatherings $A, B-K, L-20$ leaves numbered 1-40.

Paper: Leaf size 26.5 x $20 \mathrm{~cm}$.; title page watermarked 1818, smooth. Plates are impressed on thicker paper, no marks, smooth.

Notes.

A Selection from the Psalms of David, a psalm book with tunes, is the earliestfound musical publication of the Church of England in Canada. Is is an adaptation of an English psalter of the same title compiled by Dr. Edward Miller, organist at Doncaster from 1756 till 1807. ${ }^{6}$ The verses are Tate and Brady's as modified by an English clergyman, the Rev. George Hay Drummond. The forty tunes, set in four parts, are presented in open score with a figured bass for the keyboard accompanist, the inner parts indicated by small stemless notes on the staffimmediately above the bass. The copper plate engraving is very beautifully executed.

Other Copies: Anglican Church Archives, Toronto; University of British Columbia; McGill/Lande; National Library of Canada; Queen's University.

LINTON, George W. The Vocalist. Toronto [186?] .

Copy Described: McGill/Lande.

Title.

THE VOCALIST; [arched] | [within the arch] A COLLECTION OF 313 | TUNES, ANTHEMS AND CHANTS । OLD AND NEW. DESIGNED FOR THE | CHOIR, CONGREGATION, AND SINGING CLASS; | CONTAINING A I CHOICE SELECTION OF TUNES OF EVERY VARIETY OF METRE IN GENERAL USE. I ALSO, I Fourteen Chapters on Music, and two on Versifi=

${ }^{6}$ D.F. Cook, "A Survey of Hymnody in the Church of England in Eastern Canada to 1909." The Journal of the Canadian Church Historical Society 7 (1965): 41. 
cation and Chanting. I BY I GEORGE W. LINTON. I TORONTO, C.W. I PUBLISHED BY THE AUTHOR.

\section{Collation.}

Impossible to determine by observation alone: the leaves are unsigned, and the copy examined while in rather delicate condition remains very tightly bound. 104 leaves, pp. 1-4 5-27 28-208 [=4, 23, 181].

\section{Technical Notes.}

Printing Process: The music is engraved, $140 \times 217 \mathrm{~mm}$. (tune 267).

Paper: Leaf size 16 x $23.8 \mathrm{~cm}$.; no marks, smooth, white.

\section{Contents.}

1 title, 2 Preface, 3 Elementary Index, 4-27 Elements of Music, 28 blank, 29-208 music. Three indexes referred to in the Preface are missing.

\section{Notes.}

The Vocalist is the work of an American compiler who published two collections in Canada. ${ }^{7}$ The incomplete copy seen is described in the catalogue of the Lande collection as "an extremely rare piece of Canadiana." Lande sets the probable date of publication as 1865. An advertisement for Steinway pianos on the back cover, however, refers to the award of a First Gold Medal at the Paris Exhibition Universelle of 1867 . There may have been more than one printing, or copies may have been clothed in several generations of bindings. The designation, "Toronto, C.W." on the title page does suggest a pre-confederation publication date. A very large proportion of the tunes are composed by the compiler, but the only one which discloses an obvious connection with Canada is Montreal, no. 267 , dated 1861 . The tunes are harmonized mainly in four parts and printed in open score.

Other Copies: None located.

PRESBYTERIAN PSALMODY. Montreal, 1851.

Copy Described: Metropolitan Toronto Central Library/Baldwin Room.

Title.

[within double rule frame, $12.7 \times 14.3 \mathrm{~cm}$.] THE I PRESBYTERIAN PSALMODY, I BEING A SELECTION OF TUNES FOR THE USE OF $\mid$ PRES= BYTERIAN CHURCHES, FAMILIES AND SCHOOLS, I THROUGHOUT CANADA. | [printers device $1.9 \times 8.9 \mathrm{~cm}$.] | [Gothic] Montreal: | PRINTED BY JOHN C. BECKET, NO 22, GREAT ST. JAMES STREET. I [7 mm. rule] I 1851.

\section{Collation.}

In 4s and 6s: $A^{4}(\mathrm{~A} 1+\chi 1) B^{6} C-D^{4} \mathrm{E}-\mathrm{N}^{4}$ [includes $\mathrm{I}$ and $\left.\mathrm{J}\right] 0^{4}(-04)[\$ 1$ signed] ; 62 leaves, 124 unnumbered pages.

Technical Notes.

Printing Process: The music is set in individual types, all tunes framed by

${ }^{7}$ The other: The Union Chimes (Toronto, 1866). Brown University has a copy. 
double rules $126 \times 143 \mathrm{~mm}$. $\left(\mathrm{B} 1^{\mathrm{r}}\right)$, the title of each tune separated from the music by a rule.

Paper: Leaf size $15.1 \times 16.5 \mathrm{~cm}$.; no marks, smooth, white.

\section{Contents.}

$A 1^{\mathrm{r}}-A 1^{\mathrm{V}}$ blank, $\chi 1^{\mathrm{r}}$ title, $\chi 1^{\mathrm{V}}$ blank, $A 2^{\mathrm{r}}-A 2^{\mathrm{V}}$ Address (Preface), $A 3^{\mathrm{r}}-A 3^{\mathrm{V}}$ Index, $A 4^{\mathrm{r}}-A 4^{\mathrm{V}}$ blank, $B 1^{\mathrm{r}}-02^{\mathrm{V}}$ music, $03^{\mathrm{r}}-03^{\mathrm{V}}$ blank.

Notes.

Presbyterian Psalmody is a true tune-book; words for verses other than the first are not given. Although the Address includes a few general principles to be used in order to avoid congregational singing which is "a harsh, 'jangling' confusion of sound" $\left[A 2^{\mathrm{V}}\right]$, it is by no means a theoretical introduction to music. The 100 tunes, drawn from the Anglo-Scottish repertoire are numbered consecutively in roman numerals, harmonized in four parts, and set in open score.

Other Copies: None located.

WARREN, William. A Selection of Psalms and Hymns. Toronto, U.C., 1835. Copy Described: Metropolitan Toronto Central Library/Baldwin Room.

Title.

A SELECTION | OF | PSALMS AND HYMNS | FOR EVERY | [Gothic] Sunday and principal Festival I THROUGHOUT THE YEAR, I FOR THE I USE OF CONGREGATIONS IN THE DIOCESS OF QUEBEC. I Selected and arranged under the authority and direction of | THE HON. AND RIGHT REV= EREND THE LORD BISHOP. I [1.3 cm. rule] | TOGETHER WITH A NUM= BER OF I CHANTS. I THE WHOLE OF THE MUSIC SET AND ADAPTED BY W. WARREN, I Organist of St. James's Church, Toronto, Upper Canada. I [1.8 $\mathrm{cm}$. double rule, the upper rule thicker] | TORONTO, U.C. I PUBLISH= ED BY ROBERT STANTON, I King's Printer. I 1835.

Collation.

In $4 \mathrm{~s}: 1^{4} 2-19^{4}$ [\$1 signed]; 76 leaves, pp. [4], $1-3$ 4-143 144 [4] [=4, $144,4]$.

\section{Technical Notes.}

Type: Roman. No page is typical; some are in two columns.

Music: Engraved $175 \times 130 \mathrm{~mm}$. (p. 69).

Paper: Leaf size $27.3 \times 17 \mathrm{~cm}$.; no marks, rough white.

\section{Contents.}

[4 blank] 1 title, 2 colophon statement, 3 [pointing finger] NOTE.- The Tenor and Counter-tenor parts of each tune must be sung an $\mid$ octave lower than printed, as they are written in the trebel clef. I , 4-137 words and music, 138-142 prose canticles, 143 Index to the Tunes, Index to the Chants, 144 blank, [4 blank]. 
Note.

Warren's Selection of Psalms and Hymns was the first collection authorized by the Church of England in Canada to mix hymns with metrical psalms. ${ }^{8}$ There are 125 psalms (Tate and Brady's version) and 75 hymns. The music is drawn from the standard English repertoire. Warren includes two of his own tunes, Colborne C.M., p. 69, and York New Church L.M., p. 105, as well as two chants, a Venite, p. 123, and a Nunc Dimittis, p. 137. The music is in four parts arranged in open score.

Other Copies: National Library of Canada.

BARCLAY McMILLAN

${ }^{8}$ D.F. Cook, ibid., p. 43. 


\section{$A$ \\ SELECTION \\ FROM THE \\ PSAALAMS OII IDAADIID,}

THE MUSIC (ADAPTED TO THE ORGAN AND PIANO FORTE) BY

DIR. MIILISR,

AND THE WORDS BY

P因

\section{ARRA NGED}

In such a manner, as to present, at one view, the Music in score for four Voices, und all the words appointed to be sung to each Tune, as it occurs in the General Index, )

BY

Uhe 3avo. George Tenthing, 3. 现,

CHAPLAIN TO HIS MAJESTY's FORCES,

AND

EVENING LECTURER OF CHRIST CHURCH,

RORNTESAI:O

AND

DEDICATED, BY PERMISSION,

To

The Right Revd. Father in God, Jacob,

LORD BISHOP

of

QUEBEC.

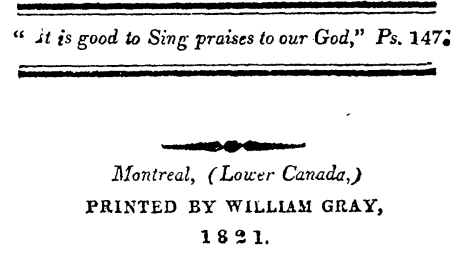




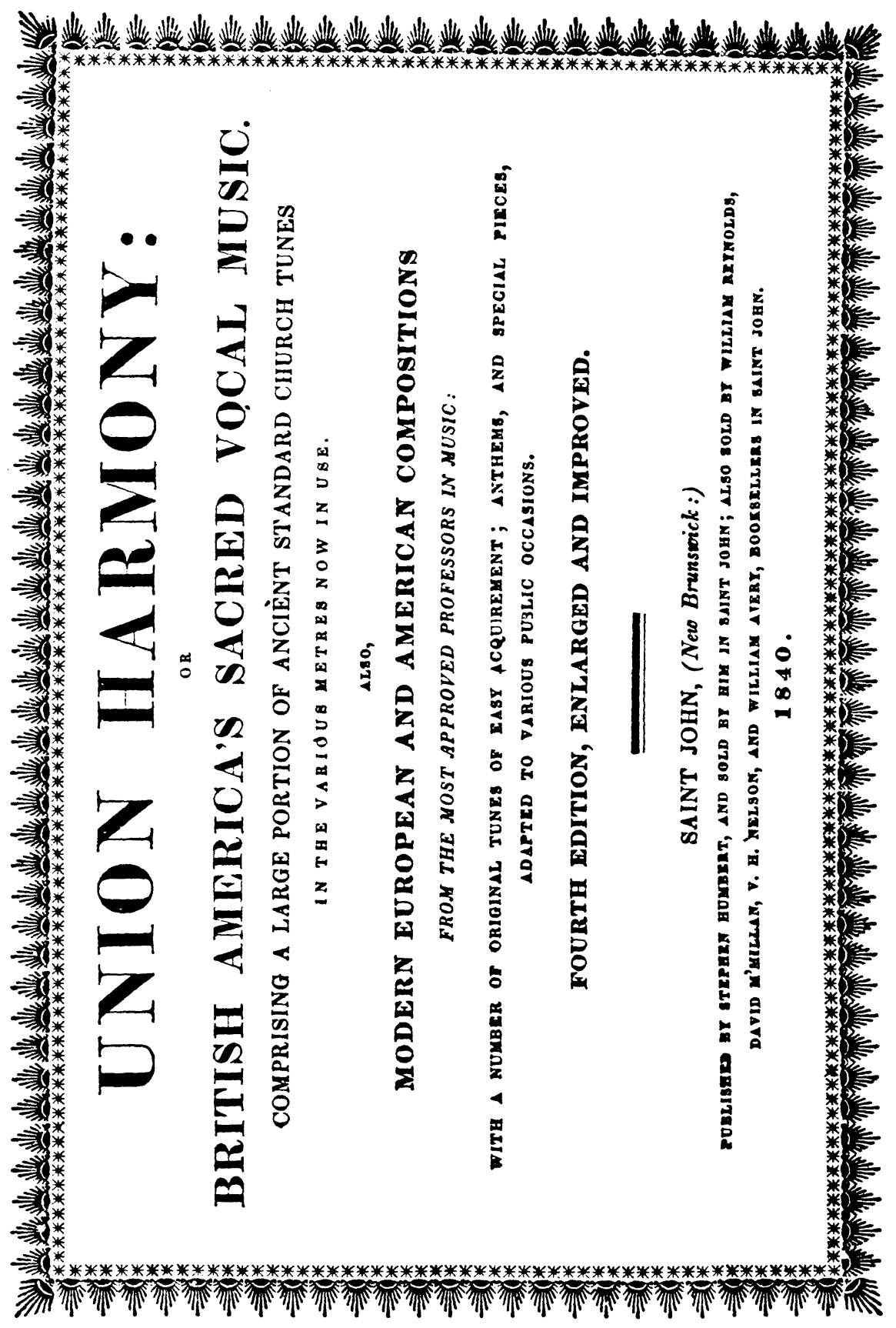




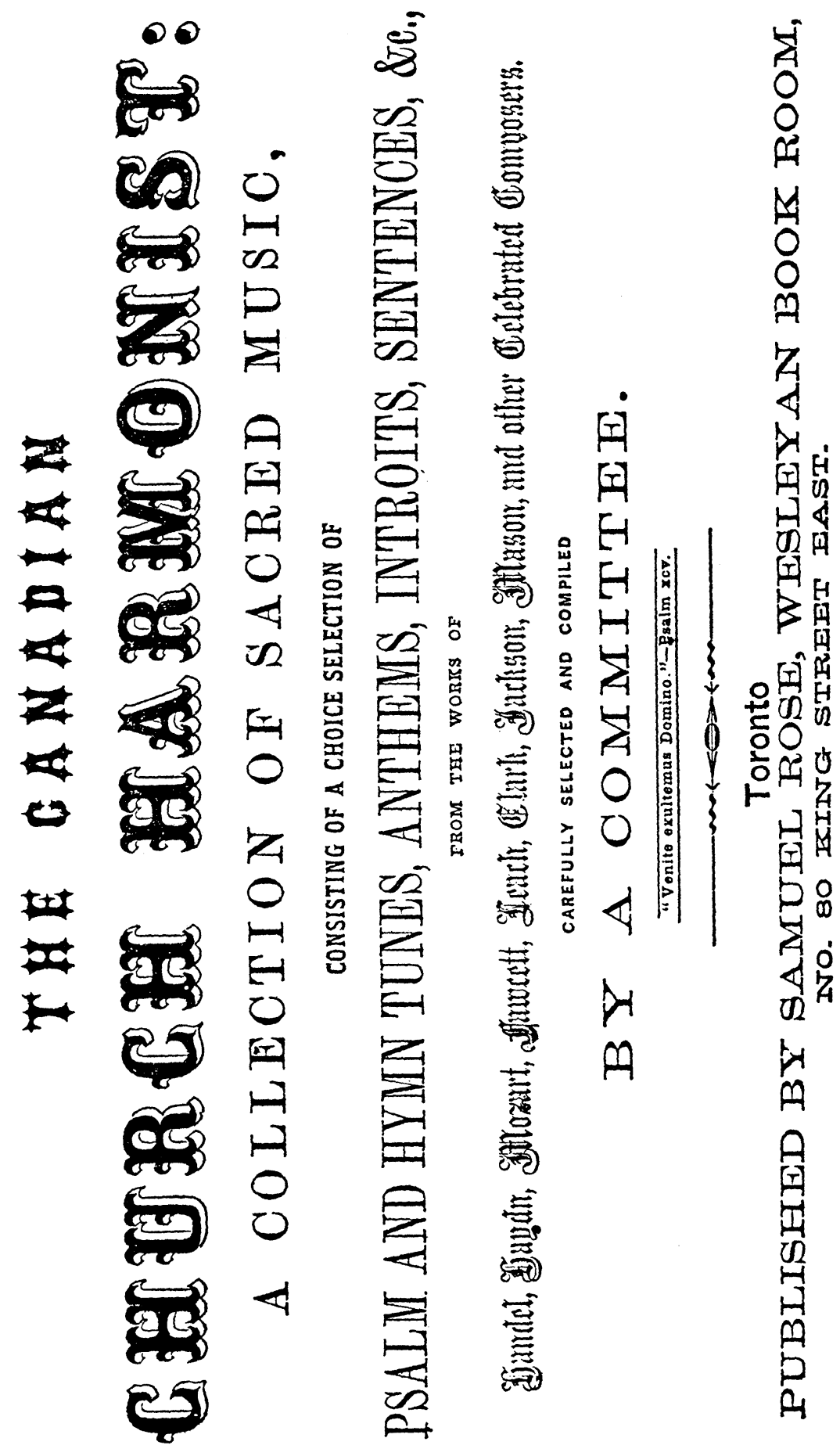




\section{CHURCH}

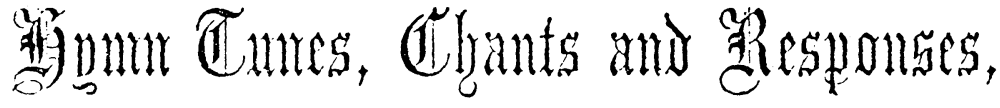 FOR THE}

SEVERAL SEASOXS OF THE CHRISTIAN YEAR,

A3 Strg in

THE CHURCH OF THE HOLY TRINITY, TORONTO.

SELECTED AND EDITED

Aluter the Sanction of the Cilergul,

$B \Gamma$

H. R. FRIPP, ORGANIST AND CHOIR-MASTER.

Printed for the use of the Congregation.

UIDIXกto;

PRINTED AT THE "GUARDIAN" STEAM PRESS.

1861.

For Sale by H. Rowsell. 

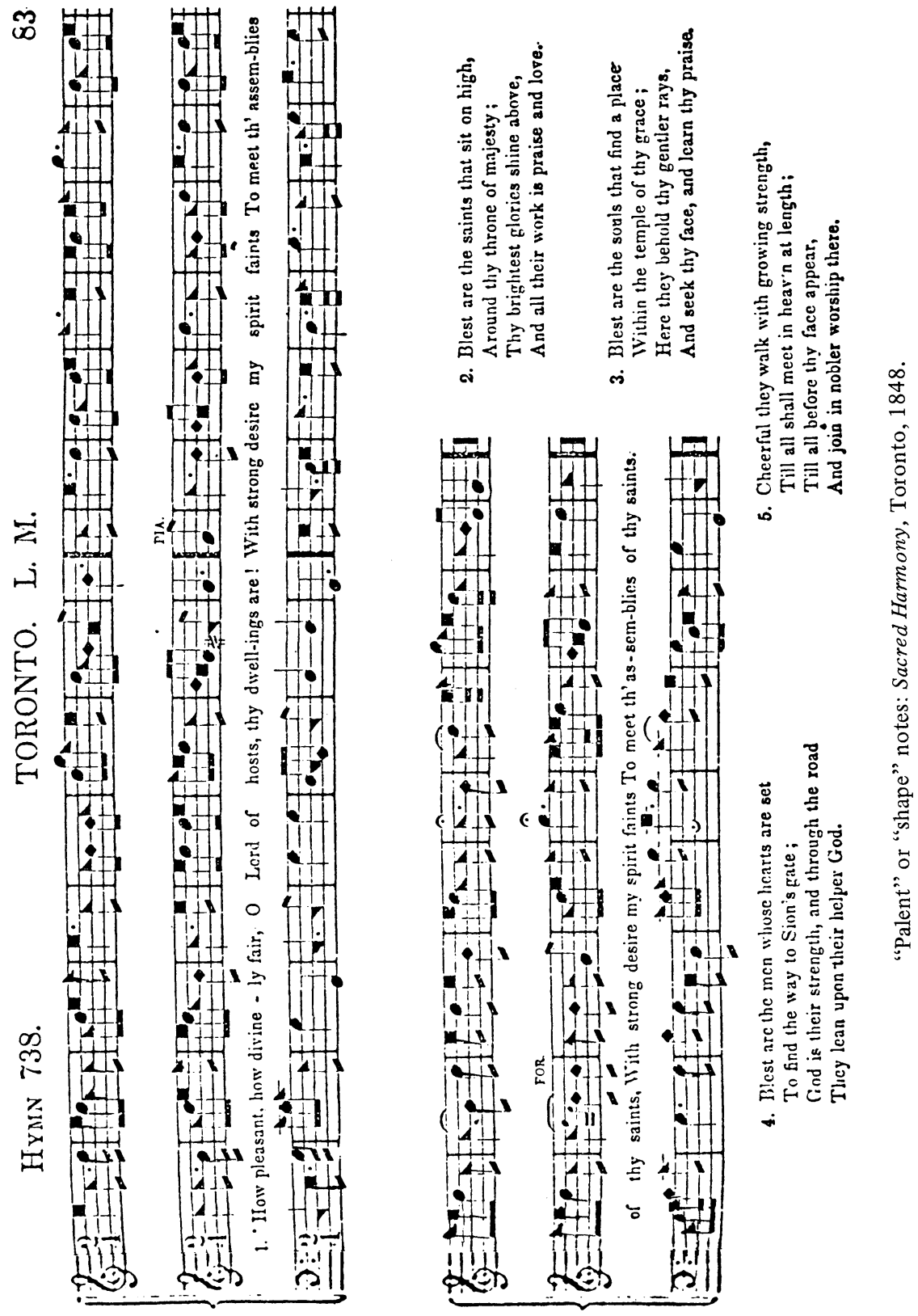